Vidyodaya J., of Sci., (1992) Vol. 4, No. 1, pp: $179-189$

\title{
SEASONAL DIURNAL AND VERTICAL DISTRIBUTION PATTERNS OF CYCLOPID COPEPODS IN KOTMALE RESERVOIR
}

\author{
W. P. N. Chandrananda ${ }^{1}$ and S. Piyasiri ${ }^{2}$ \\ 1. Department of Zoology, \\ Open University, \\ Nawala, Sri Lanka.
}

2. Department of Zoalogy, University of Sri Jayewardenepura, Nugegoda, Sri Lanka.

Received on : $02-12-1992$

Accepted on : 20-04-1993

\begin{abstract}
Vertical distribution of cyclopid copepcds was studied in Kotmale reservoir, in order to determine the variation in zooplankton at different depths. Their seasonal distribution and migratory patterns were also studied.

Vertical and horizontal sampling were done at monthly intervals from August 1990 to December 1991. Two diurnal samplings were done; one when water level was low $(40 \mathrm{~m})$ and the other when it was high $(62 \mathrm{~m})$.

The two cyclopid species identified were Mesocyclops leukarti and Thermocyclops crassus.

Cyclopid adults and their immature stages were abundant at all depths. However their population density decreased with increasing depth. Highest density was found within the range of surface to ten meters.

They showed striking diurnal migration which was independent of the intensity of sunlight. The migratory pattern of adults and young was not much different.

The seasonal variation observed did not show the same pattern during both sampling years. During the latter part of the study (October to December 1991) a large decrease in cyclopid population was observed which was correlated with the collapse of green algae population and the appearance of algal bloom caused by blue green algae (Microcystis aeruginosa).
\end{abstract}

Key words - cyclopid copepods, copepodid stages, diurnal migration, seasonal \& vertical distribution, population structure. 


\section{Introluction}

Kotmale reservoir is a tropical oligomictic water body situated in the central part of Sri Lanka at longitude $7^{\circ} 03^{\prime}-i^{\circ} \mathrm{J} 5{ }^{\prime} \mathrm{N}$ and latitude $80^{\circ}$ $36^{\prime}-80^{\circ} 41^{\prime} \mathrm{E}$.

Kotmale reservoir was constructed by damming one of the uppermost branches of the river Mahaweli; the Kotmala Oya, under Accelerated Mahaweli Development Project.

The major purpose of this reservoir is to generate hydroelectric power.

The morphometric data of it, are summarized as; surface area $6.5 \mathrm{~km} 2$, maximum length $6.8 \mathrm{~km}$ and maximum width $1.41 \mathrm{~km}$. Its maximum capacity at full supply level is $703 \mathrm{~m}$.

The main supply of water to the reservoir is from Kotmala Oya, Pundalu Oya and Puna Oya. Fig. (1).

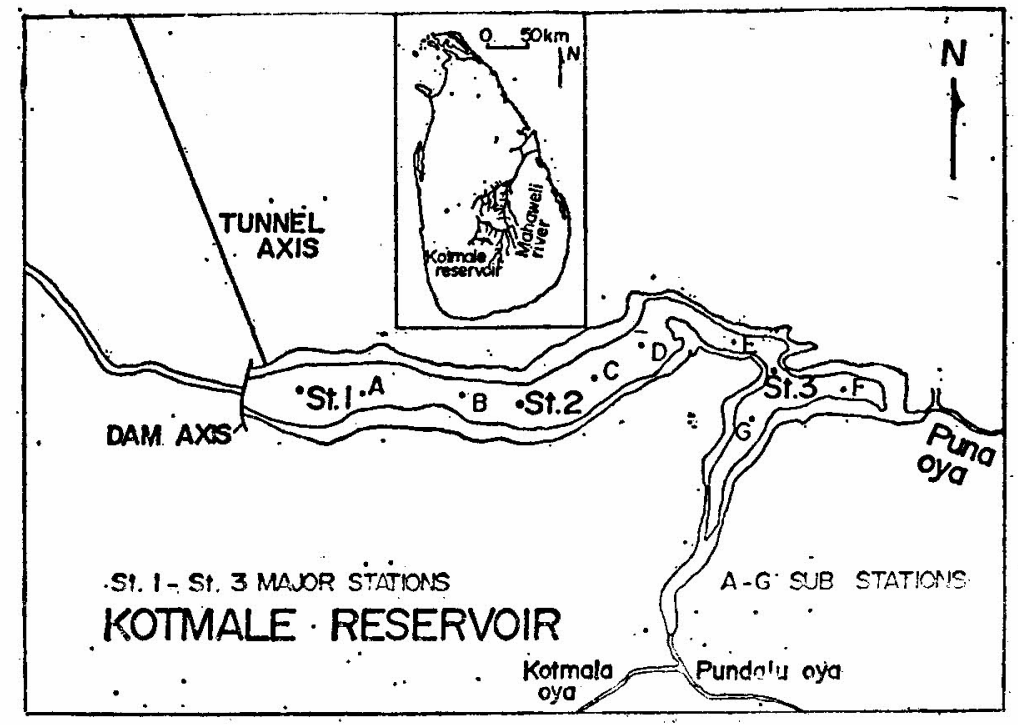

Fig. 1. Location of Kotmale reservoir and sampling stations

The water level is subjected to frequent fluctuations, mainly due to high out flow of water for power generation and due to seepage through the dam.

Limnological characteristics of Kotmale reservoir show that the water is slightly alkaline, with surface temperature in the range of $23.0-28.0^{\circ} \mathrm{C}$, $\mathrm{pH}$ in the range of $5.1-8.3$, surface dissolved oxygen concentration in the 
range of 5.0-6.8 mg/1 secchi depth (near the dam) in the range of $2.3-2.8 \mathrm{~m} \&$ total alkalinity in the range of $0.1-0.6 \mathrm{meq} / 1$. Kotmale reservoir was thermally stratified throughout the investigation pericd.

The reservoir has a fairly high zooplankton and phytoplankton community. Green algae and Blue green algae represent the phytoplankton. Mainly Diatoms are present but in very low numbers.

The zooplankton found in Kotmale reservoir were typically limnetic (Fernando 1980 a). However the number of species found were smaller than those found in temperate lentic water bodies.

This study presents some work done on cyclopid copepods in Kotmale reservoir. The results given here are based on investigations carried out from August 1990 to December 1991.

\section{Materials \& Methods}

Single sampling location was selected closer to the dam, as it will provide an opportunity to study diurnal, vertical \& seasonal distribution pattern of zooplankton comparatively. This sampling site was chosen under the assumption, that all the plankton types are present there, as the current of water is mostly towards the dam.

Highest water levels were observed close to the dam throughout the year. Collections were made once a month between 11.00 a.m. to 12 noon using a closing type net with a mesh size of $50 \mu \mathrm{m}$ and a diameter of $30 \mathrm{~cm}$.

In order to study vertical distribution, vertical sampling was done by filtering each $10 \mathrm{~m}$ column of water starting from surface to bottom (surface$10 \mathrm{~m}, 10 \mathrm{~m}-20 \mathrm{~m} \& 20 \mathrm{~m}-30 \mathrm{~m}$, etc.)

Horizontal tow net sample was also taken in order to study the abundance of zooplankton in surface layers.

All these samples were preserved in $4-5 \%$ formalin and transported to the laboratory for further investigations.

Each vertical sample was diluted upto $100 \mathrm{ml}$ and horizontal sample upto $150-200 \mathrm{ml}$ (depending on the concentration of phytoplankton). Five sub samples from each sample $(1 \mathrm{ml}$ each) were counted using a sedwick rafter cell and a microscope with an eye piece micrometer.

All the sub samples were used in identifying the zooplankton \& for enumeration of the density of each plankton type. These measurements were used in determining vertical distribution, seasonal variation and population density. In addition, eggs of cyclopids and nauplii stages were also counted. 
To determine the total and standard body length and the width, $90 \%$ of the individuals in all five sub samples were examined. Measurements were taken from anterior end of the cephalothorax to the tip of the furcal rami (total length) and the maximum width of the cephalothorax.

Two diurnal samplings were done, one (during low water level $(40 \mathrm{~m})$ ) in April 1991 and the other (during high water level (62m)) in November 1991. On both occasions sampling was started at $06.00 \mathrm{a}$.m. and continued at 6 hourly intervals (12.00 noon, 06.00 p.m. and 12 mid night).

The samples obtained in the diurnal investigations were also treated and counted in the similar way as described earlier. These samples were used in determination of diurnal migration.

Gut content analysis of the major fish types (Oreochromis mossambicus, Puntius sarana \& Cyprinus carpio) present in Kotmale reservoir also was conducted in order to obtain information of predation pressure on zooplankton by fish.

\section{Results}

Zooplankton community in Kotmale reservoir comprised of several taxonomic groups such as rotifers, copepods and cladocerans. All these groups are very common in tropical countries as well as in other water bodies in Sri Lanka.

The annual mean percentage of each group is shown in Fig.

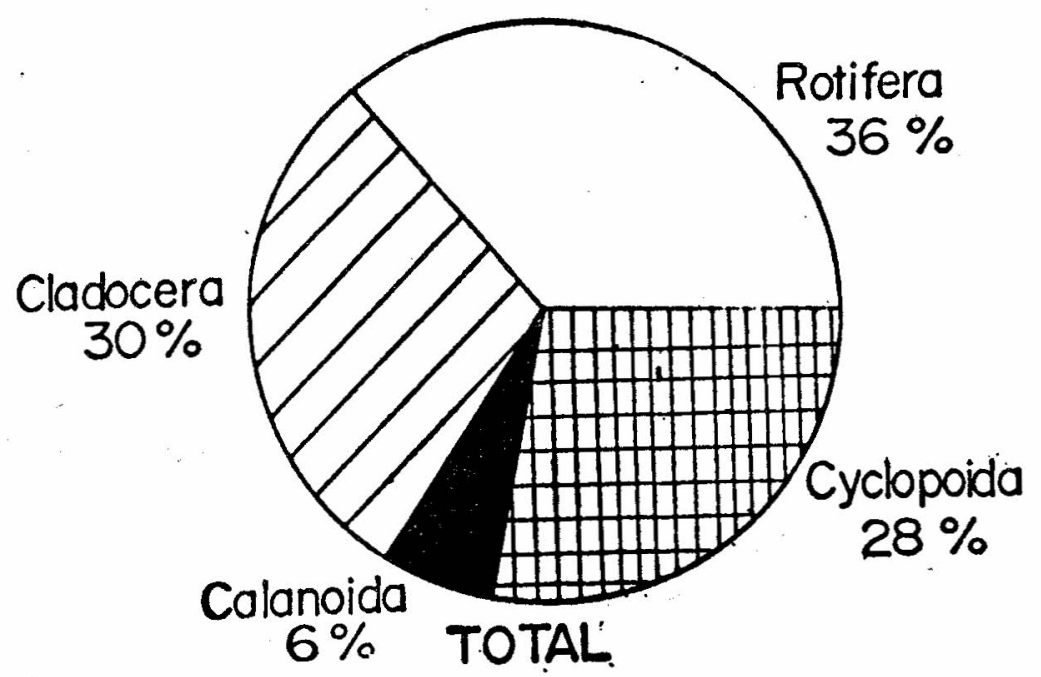

Fig. 2. Annual mean percentage of various taxonomic groups of zooplankton 
Among copepods two species were identified namely Thermocyclops crassus \& Mesocyclops leukarti: which are limnetic species. M. leukarti is a very common species in tropical countries as well as in other water bodies in Sri Lanka (Fernando 1980 a).

These two species alone comprised of a large proportion of zooplankton in the reservoir. In certain months they were dominating over all the other zooplankton. (Fig. 3). To determine the distribution and seasonal variation both species of copepods were counted together.

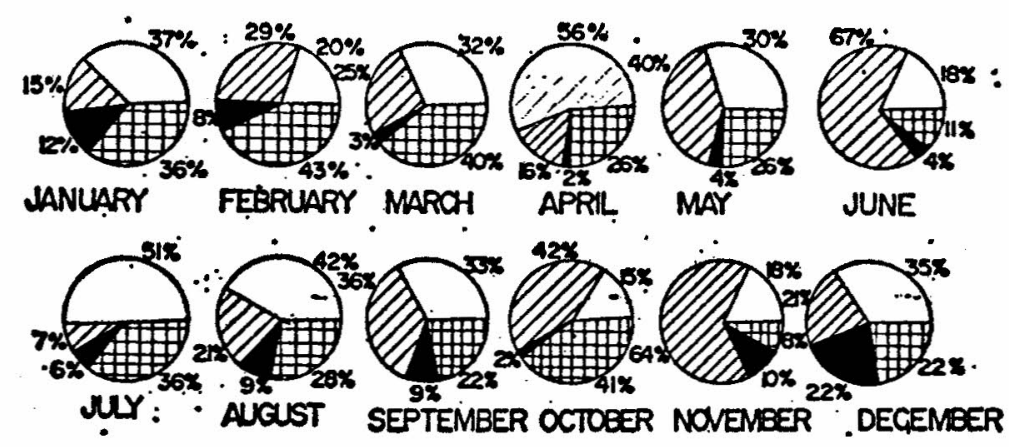

Fig. 3. Monthly mean percentage of zooplankton groups

Free eggs, nauplii and copepodid stages were present throughout the year indicating continuous reproduction, inspite of the temperature differences, thermal stratification and the water level fluctuations.

The percentage of eggs were higher during cold weather and rainy months indicating that the egg production is dependent on temperature. The nauplii population was very high throughout the year. It comprised of a large portion of zooplankton. The densities of nauplii were always higher than the densities of total copepodites on the same date, (Fig. 4). The population structure of nauplii was mainly composed of small individuals with body size in the range of $0.09 \mathrm{~mm}$ to $0.15 \mathrm{~mm}$. Their population decreased with increasing body size. This was mainly due to invertebrate predation and predation by fish. The possible invertebrate predators were rotifers such as Asplanchna, insect larvae such as corithrid larvae and coelenterate medusae. All these types were voracious feeders. Gut contents of $O$. mossambicus showed nauplii, with the body size of $0.12-0.18 \mathrm{~mm}$. This shows nauplii population was under heavy predation. Final nauplii stages were comparatively less in the population. They were in the body range of $0.27-0.33 \mathrm{~mm}$. 


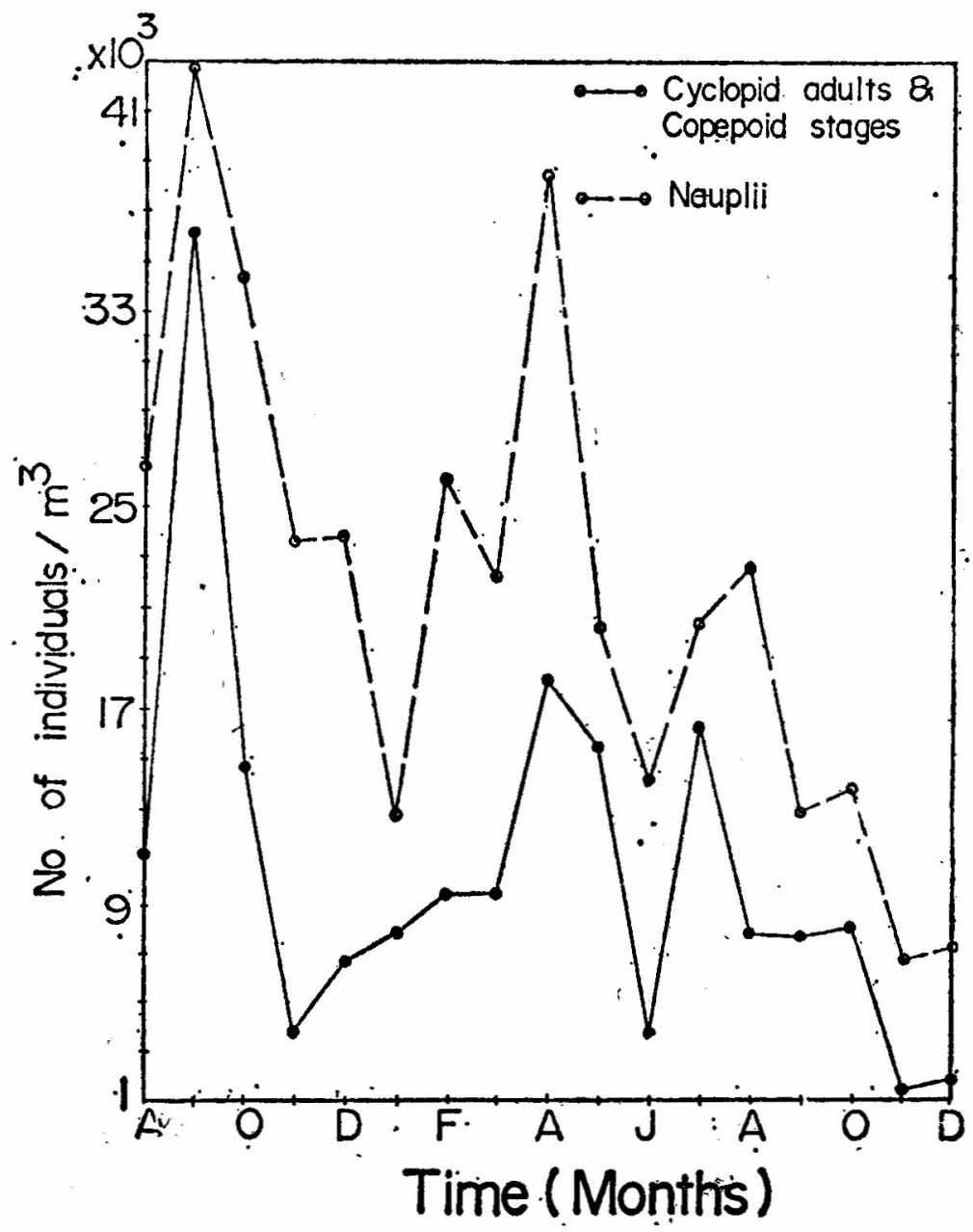

Fig. 4. Seasonal variation of cyclopids and nauplii stages

A larger part of cyclopid population was represented by copepodids of all stages. There were instars of stage I to stage IV. Among these the copepodids of stage I \& II were the most abundant. Their body lengths were in the range of $0.36-0.42 \mathrm{~mm}$.

The body sizes of different stages of these instars varied during certain months. The body length of stage I was generally $0 . .36 \mathrm{~mm}$. However the body length of stage I was between $0.27 \mathrm{~mm}$ and $0.30 \mathrm{~mm}$ during warm months which showed a reduction in bcdy length. This observation was very clear in May 1991 during which the surface mean temperature increased up to $26^{\circ} \mathrm{C}$ and the mean temperature at $10 \mathrm{~m}$ depth also increased up to $24^{\circ} \mathrm{C}$. (this was 
the highest temperature recorded during that year for $10 \mathrm{~m}$ depth). This shows that there is a correlation between the decreased body size of copepods and increased temperature.

This observation was more emphasized by the population structure within the period of Augurt to December 1990, when comparatively low temperatures (surface not more tha $a_{i i} 25.2^{\circ} \mathrm{C}$ ) \& higher water level (above $55 \mathrm{~m}$ ) were prevailing. Within this period the population consisted larger copepods, which were in the range of $0.36-0.42 \mathrm{~mm} \&$ the size range of $0.27-0.30 \mathrm{~mm}$ were missing in the population. (Fig. 5).

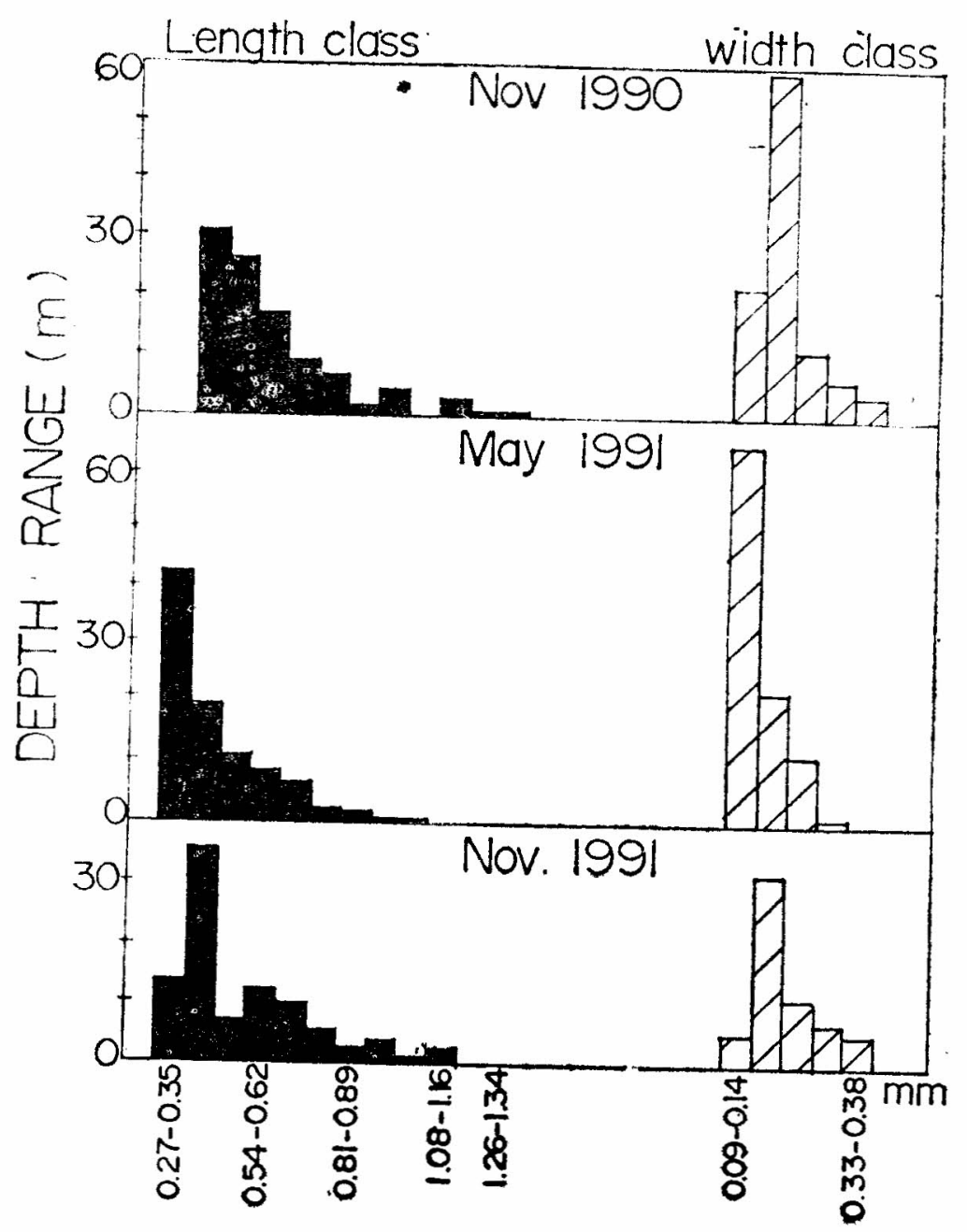

Fig. 5. Population structure of cyclopids 


\section{Seasonal Variation}

The seasonal variation in the population structure was very striking. Both adult cyclopids and their copepodid stages showed striking seasonal variation. The variations between the two years were also quite significant. The copepodid stages showed two striking maxima, one in September 1990 and another low peak in April 1991. This could be explained as an increase of the population during warm season. In April 1991 the surface temperature has increased up to $28^{\circ} \mathrm{C}$ at noon while in September 1990 it was $26.7^{\circ} \mathrm{C}$ at the same time. There was a striking difference between the seasonal variation of copepcdid stages and adults. In certain months population of the copepodid stages were higher than the adults. This was mainly due to size selective predation by fish. Gut contents of Cyprinus carpio \& fingerlings of $O$. mossambicus showed that they prefered cyclopids and calanoids than the other zooplankton. The prey size range of above fish types were mainly $0.99-1.25 \mathrm{~mm}$. This indicates that high predation by fish, controls the cyclopid population to a great extent.

However the density of both copepod \& cyclopid stages decreasied after November. The reduction of their population may be indirectly due to blue green algae Microcystis bloom which appeared in late September (Fig. 4).

The bloom affected the green algae population greatly, which was the main food source of nauplii stages. The population of nauplii decreased into low levels during this period. Their population may have also been affected by canibalism of copepodid stages. Number of copepodid eggs in the population also decreased during this period.

\section{Vertical Distribution}

Both the adults and the copepodid stages were distributed throughout the water column. However their densities decreased with increasing depth.

Most of the individuals were occupying either the surface or within the surface to $10 \mathrm{~m}$ depth range, at 11.00 a.m. to 12.00 noon. (Fig. 6) This distribution pattern was changing within the year. Distribution pattern of adults and copepodid stages were identical at times. There were rare occasions where copepodid stages showed completely different distribution patterns. However, the density of copepodid stages in deeper layers were always higher than the adults. At times higher concentration of copepodid stages were observed even within the range of $30-40 \mathrm{~m}$ (Fig. 6) Their abundance at deeper layers may be to avoid heavy predation by fish. Generally fish population density was higher in epilimnetic waters, between surface to $20 \mathrm{~m}$ depth. 


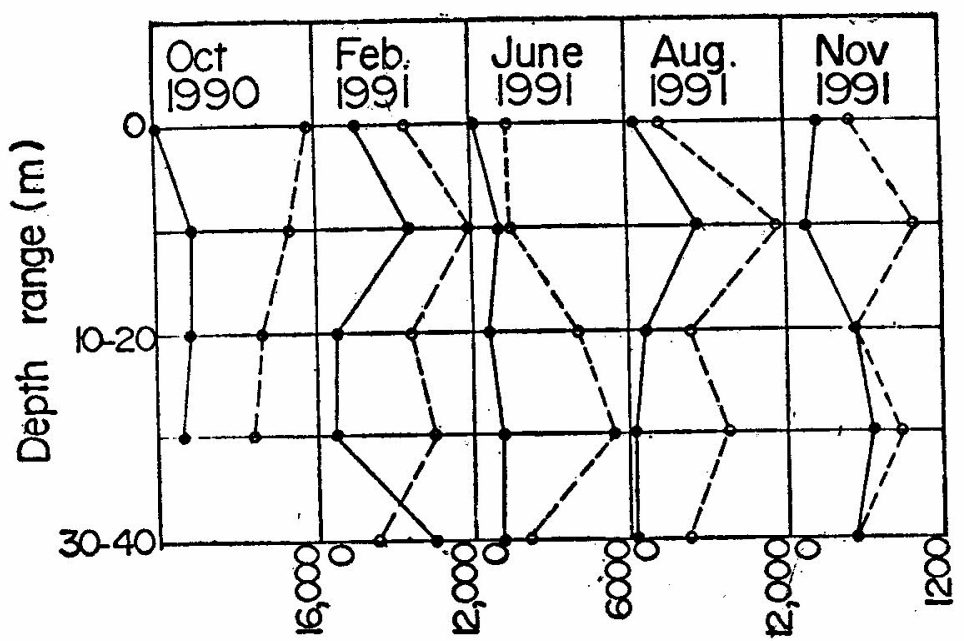

No. of individuals $/ \mathrm{m}^{3}$

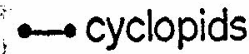

a-o copepodid stages

Fig. 6. Vertical distribution of cyclopids and copepodid stages

\section{Diurnal Variation}

Diurnal variation of copepods showed slightly different results. Their migration seemed to be independent of the intensity of sun light. They may be changing their location to avoid the higher densities of fish population (Fig. 7). Even at 12 noon, inspite of the high intensity of sunlight they occupied the surface layers during one sampling occasion (when water level was low). However, the results of the second diurnal sampling showed that they occupied deeper layers too. At $6.00 \mathrm{a} . \mathrm{m}$. higher density of individuals were found along the whole water column at one sampling occasion while in the second investigation, population density was high at the surface.

The diurnal distribution pattern of adults and the copepodid stages was not much different.

\section{Discussion}

The zooplankton population found in Kotmale reservoir, are typically tropical as in the other Sri Lankan water bodies. (Fernando 1980 a \& b). The three major groups of zooplankton found in the reservoir were rotifera, cladocera \& copsp $>d a$. 


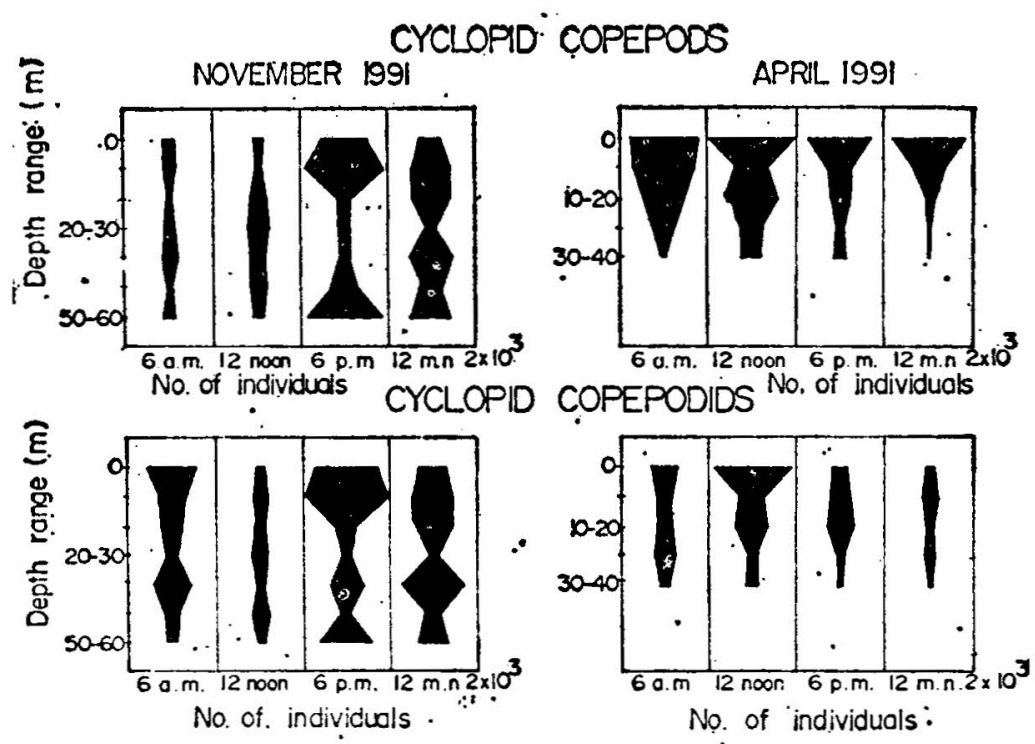

Fig. 7. Diurnal migration of cyclopids and copepodid stages

Among the above groups, the most abundant group recorded in Victoria reservoir was copepoda (Piyasiri \& Jayakody 1991). However in Kotmale reservoir the densities of all three groups varied seasonally.

In Victoria reservoir the highest densities of copepods were recorded from May to June. (Piyasiri \& Jayakody 1991). The studies of Vijverberg (1977) in Tjeukemeer showed highest densities of copepods in late Spring and Summer; both cases in warm months. In Kotmale reservoir similar observations were recorded. However higher densities wcre observed in September \& October too, which were not considered as warm months. Inverse correlation between body size \& temperature of copepods observed in Kotmale reservoir, has been experimentally shown by Piyasiri (1985) for Phyllodiaptomus annae.

According to Vijverberg (1977) the copepod populations in Tjeukemeer reproduced continuously. Similar conditions were recorded by Piyasiri \& Jayakody (1991) in Victoria reservoir. Similar results were obtained from Kotmale reservoir. According to Vijeverberg (1977) copepodites stages I and II and the adults were the most abtindant stages of the population structure and the nauplii stages were always more than the adults. In Kotmale reservoir the highest numbers were always obtained in copepcdite stages I \& II but not the adults. However the nauplii stages were always high. stages.

According to Vijverberg (1977) mortality acts on all copepodite 
Population structure in Kotmale reservoir indicates that the mortality is higher on adult forms than on juveniles due to high predation, as the predation pressure is higher on cyclopids with large body sizes.

Size selective predation of fish has been explained in detail by Brooks and Dodson, (1965) and Zaret T.M. (1969). In Kotmale reservoir the main predators of cyclopids are Cyprinus carpio and fingerlings of $O$. mossambicus.

The composition of zooplankton in Victoria reservoir and Randenigala reservoir has not changed during the past few years (Piyasiri \& Jayakody 1991; personal communication with Piyasiri). Similar conditions were observed in Kotmale reservoir from 1990 to 1991.

According to Piyasiri \& Jayakcdy (1991) the copepod density was high at the surface to $5 \mathrm{~m}$ depth and their density decreased with increasing depth. Zaret (1980) has stated that copepcds descended rapidly from surface waters at dawn, and concentrated near the bottom of the lake during day time, but during late afternoon they migrated upward. Further Zaret (1980) has observed the same pattern, less striking for the copepodids, and even weaken pattern was observed for the nauplii. However in Kotmale reservoir majority of individuals were occupying the surface to $10 \mathrm{~m}$ depth range and they seem to be occupying the surface layers throughout the day. However a considerable proportion of the population was also occupying deep layers. The vertical distribution or diurnal migration of adults and ccpepcdid stages was not much different. Their migration pattern was not infiuenced either by sunlight or predation.

\section{References}

Brooks J.L. \& Dodson. S.I. (1965) : Predation, body size and compositicn of plankton Science $150: 28-35$.

Fernando C.H. (1980 a): The fiesh water zooplankton of Sri Lanka with a discussion of tropical fresh water zooplankton composition. Int Revue ges Hydrobiol 65: $85-125$

Fernando C.H. (1980 b) : The species and size composition of tropical freshwater zooplankton with special reference to the Oriertal region (South East Asia Int Revue ges Hydrotiol 65: 411-426

Vijverberg J. (1977) : Population structure life histories and abundance of copepoda in Tjeukemeer The Netherlands Populatiedynamika en produktie van zooplankton in het Tjeukemeer $41-50$.

Piyasiri S. (1985) : Dependance of food on growth and development of two fresh water tropical and temperate calanoid species Verh internat Verein Limnol. 22 : 3185-3189.

Piyasiri S. \& Jayakody. J.K.U. (1991) : Ecology of zonplarkton in Victoria reservoir. Sri Lanka : Composition ard pcpulation structure of the zooplankton. Verh Internat. Verein. Limnol. 24:1430-1435.

Zaret T.M. (1969) : Predation balanced polymorphism of Ceriodaphnia cornuta Sars. Limnol. \& Oceanog. $14: 301-303$

Zaret T.M (1980): Predation \& fresh water communities 5: 70-90. 